\title{
AZ EU-ETS PIAC HATÉKONYSÁGÁNAK VIZSGÁLATA
}

2005. január 1-jével kezdetét vette a világ legnagyobb szennyezési jog kereskedelmi rendszere, az európai szennyezésijog-kereskedelem. Mivel a szennyezési jogok ezen a piacon teljesen homogének, és nagy számban vannak egyszerre jelen, ezért tốzsdei áruként viselkednek, így egységes árfolyamuk alakul ki. A szerzố dolgozatában megvizsgálja magát a kereskedett terméket, illetve a szennyezésijog-piacot is. Megállapítja, hogy hosszú idôsort vizsgálva az árfolyamváltozások nem, rövid távon azonban normális eloszlással bírnak. Annak bizonyítására, hogy Fama (1970) értelmezése alapján közepesen hatékonynak tekinthetô a piac, az eseményelemzés eszközét használja. Ennek során két eseményt elemez részletesen: a 2006. április végi, május elejei árzuhanást, amikor néhány nap leforgása alatt a felére esett az árfolyam, illetve a 2006. decemberben lévố magyar kvótaaukciót.

\section{Kulcsszavak: EU Emission Trading Scheme (EU-ETS), piaci hatékonyság}

2005. január 1-jén hivatalosan is kezdetét vette az Európai Unió Szennyezésijog Kereskedelmi Rendszere (EU Emission Trading Scheme, EU-ETS). A szabályozás alá tartozó létesítmények csak az egyes tagállamoktól kapott kibocsátási kvóta birtokában szennyezhetnek, de ez a jog átruházható, így a vállalatok két eljárás közül választhatnak: csökkentik szén-dioxid-kibocsátásukat, és az így felszabaduló kvótáikat a piacon értékesítik, vagy folytatják eddigi tevékenységüket, és ha kibocsátásuk meghaladja az év elején kapott kvótáik számát, akkor kvótaszükségletüket a kialakuló piacon szerezhetik be. Így a szennyezési jogoknak kialakul egy árfolyamuk, ezáltal tôzsdei áruvá válnak.

Dolgozatunkban vizsgáljuk a kialakuló kibocsátási egységek árváltozását és annak eloszlását. Fő kérdésünk annak elemzése, hogy a múltbeli, illetve a mindenki számára elérhető információk is beépülnek-e az árakba, azaz Fama (1970) értelmezése alapján közepesen hatékonynak mondható-e ez a piac. Ennek a kérdésnek a megválaszolásához két eseményt vizsgálunk részletesen: a 2006. április végi, május elejei árzuhanást, amikor néhány nap leforgása alatt a felére esett az árfolyam, illetve a 2006. decemberben lévő magyar kvótaaukciót.

Ezen elemzés elvégzése azért is nagyon fontos, mivel az EU-ETS bevezetésével egy teljesen újszerú piac vette kezdetét, így érdemes megvizsgálni, hogy az in- dulás utáni két esztendô milyen tanulságokkal szolgál ezen piac múködésével kapcsolatban.

\section{Az európai szennyezésijog-kereskedelem}

A Kiotói Jegyzókönyvet aláíró államok vállalták, hogy átlagosan 5,2\%-kal csökkentik üvegházgáz-(ÜHG) kibocsátásukat a 2008-2012-es időszak átlagában a bázishoz viszonyítva (a legtöbb ország esetében a bázisév 1990, azonban a volt szocialista országokban ennél korábbi dátumhoz viszonyítanak, Magyarország esetében a bázis az 1985-87-es évek átlaga). A jegyzókönyv meghatározta, hogy az üvegházhatású gázok csökkentése milyen módon érhetô el, valamint minden egyes országra külön-külön előírta, hogy mekkora lehet az ÜHG kibocsátása 2008-2012 között a bázisévhez viszonyítva. A kiotói cél teljesítése érdekében az Európai Unió 2003. október 13-án elfogadta a 2003/87/EK irányelvet, amelyben lefektették az ÜHG-csökkentés és a szennyezésijog-kereskedelem fóbb alapelveit.

Az irányelv értelmében a meghatározott létesítmények 2005. január 1-jétôl csak kibocsátási engedély birtokában bocsáthatnak ki szén-dioxidot, és kötelesek kibocsátásaikat nyomon követni, és azokat évente bejelenteni. Az engedély kötelezi a létesítményeket, hogy minden év végén annyi ún. „szén-dioxid-kibocsátási egységgel" (EUA - EU Emission Allowances) 
számoljanak el, amennyi tonna szén-dioxidot az adott évben kibocsátottak. Ha éves kibocsátásuk meghaladja a megengedett szintet, akkor más piaci szereplóktól kell jogokat vásárolniuk. Abban az esetben viszont, ha tényleges kibocsátásuk kevesebb, mint amennyi joggal rendelkeznek, akkor két alternatíva közül választhatnak: eladják szennyezési jogukat, vagy bankolják azt, azaz átviszik a következó évre.

Az EU-ETS két időszakot határozott meg. Az elsô, 2005-2007-es, ún. próbaidőszakot, illetve egy második, éles időszakot (2008-2012). Az irányelv 9. cikkelye értelmében minden egyes országnak - köztük az újonnan csatlakozóknak is - ki kellett dolgozni egy Nemzeti Allokációs Tervet (GKM, 2003). Ennek célja, hogy az egyes országok bemutassák, hogyan kívánják elérni a szükséges csökkentést. Ezen dokumentumban került meghatározásra az irányelv által érintett létesítmények számára a 2005-2007 között kiosztható összes kibocsátásiegység-mennyiség, illetve az egységek egyes létesítmények közötti szétosztására vonatkozó szabályozás. Az érintett létesítmények közé azon iparágak vállalatai tartoznak, amelyek jelentôs pontszerú, nem diffúz ÜHG-kibocsátással rendelkeznek, és összesítve az Európai Unió ÜHG-kibocsátásának 46\%-át adják. Ezek alapján közel 12000 vállalat tartozik az EU-ETS hatálya alá, amelyek a kiosztási listák alapján közel 2,1 milliárd tonna $\mathrm{CO}_{2}$-kibocsátási joggal rendelkeznek. Az irányelv biztosítja a jogi kikényszeríthetőséget, illetve megállapítja a bírság mértékét, amit az elsố kereskedési idôszakban (2005-2007) tonnánként 40 euróban, míg a másodikban (2008-2012) 100 euróban határoz meg. A bírság nem mentesíti az üzemeltetốt az alól, hogy a hiányt a következő évben egységek átadásával pótolja.

\section{A szennyezési jog}

Az EUA árát meghatározó tényezók két részre bonthatók: a kereslet és a kínálat oldalira. Az elóbbibe tartozik többek között az idôjárás, gazdasági növekedés, kőolaj ára, az utóbbiba a nemzeti kiosztási tervek által meghatározott kvóta mennyisége, a bankolásban bekövetkező esetleges szabályozásváltozás vagy a projektalapú emissziós kínálat mennyisége. Az EUA-árakat hosszú távon meghatáro-

Forrás: ECX zó tényezókról részletesebben 1. Pointcarbon (2004), IEA (2007) és Sijm et al. (2006).

Miután a szennyezési jogok teljesen homogének, és azokkal minden magánszemély szabadon kereskedhet, ezért kialakul egy egységes árfolyamuk, ezáltal tőzsdei kereskedésre is alkalmassá válik ez a termék. Ezt jelzi, hogy Európában ma már több tôzsdén is lehetôség nyílik EUA-kal való kereskedésre. A spotpiac nem mondható jelentôsnek, elsôsorban a decemberi lejáratú határidôs kontraktusok bírnak nagy likviditással. 2005-ben csak a tôzsdei kereskedés forgalma elérte az 5,4 milliárd -t, amely 262 millió tonna jognak felel meg, míg 2006-ban több mint 14,6 milliárd -s forgalmat (817 millió tonna) bonyolítottak le tôzsdéken, amiből látható, hogy egy dinamikusan fejlődő piacról van szó. A kereskedés több mint 75,6\%-a az amszterdami European Carbon Exchange-n (ECX) folyt, $13,3 \%$-a a francia Powernexten, $7,4 \%$-a a skandináv Nordpoolon, míg a maradék a lipcsei EEX és a grazi EXAA-n bonyolódott le (Pointcarbon, 2007). A tốzsdei árak között minimális eltérés adódik, ami elsősorban a tranzakciós költségek eltérése miatt van. Számolásaink során a legnagyobb forgalmú tôzsdéról (ECX) származó adatokat elemezzük.

\section{Az EUA áralakulása}

A következôkben röviden bemutatjuk az EUA áralakulását és a napi kereskedési mennyiség változását 2005 áprilisától.

1. ábra illetve az ECX-n történố kereskedés teljes napi mennyisége

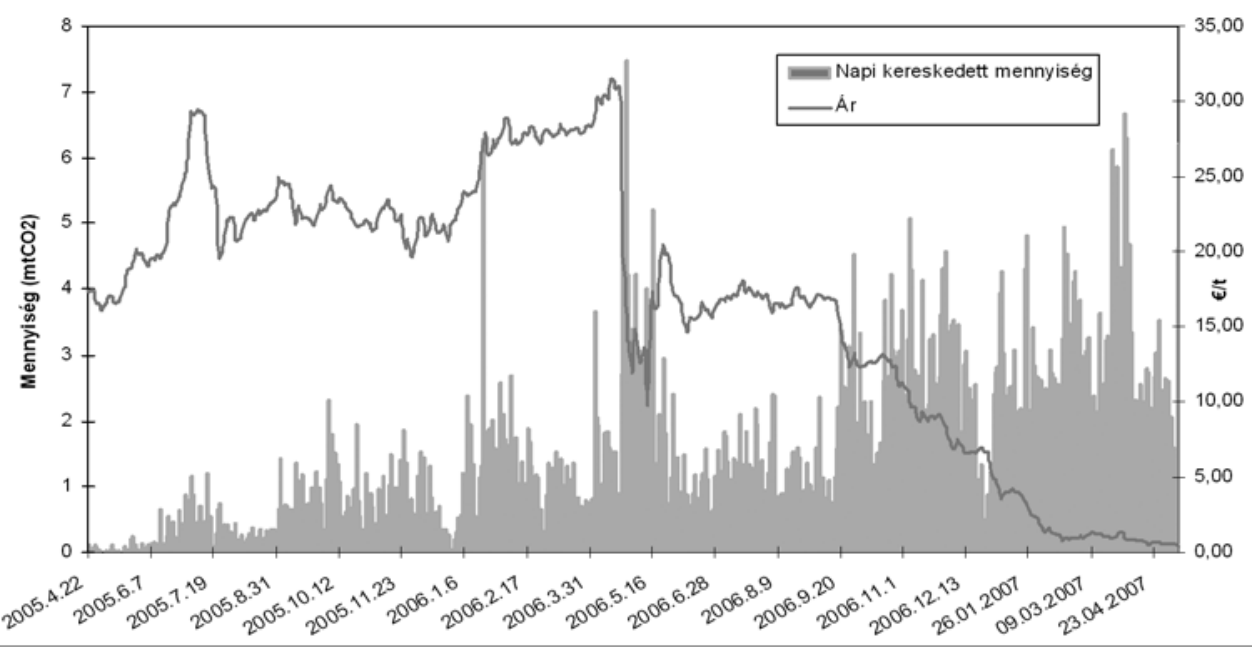

Az 1. ábra 2005 áprilisától kezdve mutatja a 2007. decemberi lejáratú EUA-árat, illetve a kereskedett mennyiséget. Látható, hogy az ár kezdetben 20-30 €/t körül mozgott, majd 2006 április végén néhány nap 
Az EUA loghozamának hisztogramja és az eloszlás fóbb mutatói

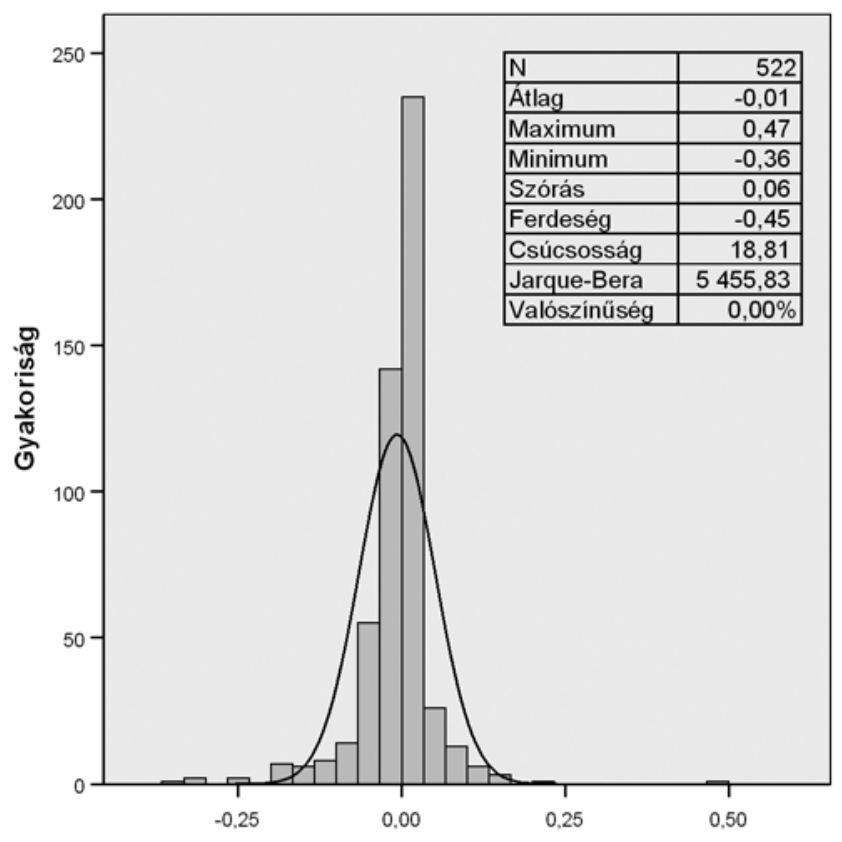

Forrás: ECX, saját számítás

alatt lezuhant $10 € /$ t-ra, majd ismét 15 eurón stabilizálódott. Ezt követően 2006. szeptember végétól folyamatosan esett az ár egészen $1 € / t$-s árfolyamig.

A kereskedési volumen kezdetben napi ötvenezer tonna körül volt, majd ez az érték 2006 elején elérte a napi egymillió tonnás átlagot, míg 2007-ben a napi hárommilliós átlagot. A kereskedés volumenének változása hasonló tendenciát mutat, mint a többi piacon, azaz nyáron és december végén kisebb a forgalom, mint az éves átlag. Az átlagosnál magasabb forgalmat bonyolítottak le a tốzsdék a 2006. április végi, május eleji keresleti sokk alatt.

\section{Az EUA áralakulásának vizsgálata}

A következókben az EUA árváltozását vizsgáljuk, teszteljük a változások közötti autokorrelációt, illetve megvizsgáljuk, hogy az árváltozás milyen eloszlással jellemezhetô. Mindkét elemzésnél az árfolyam loghozamát $\left[\ln \left(\mathrm{S}_{1} / \mathrm{S}_{0}\right)\right]$ elemezzük, mivel erról feltételezzük, hogy autokorrelálatlan, és normális eloszlást követ.

Az EUA-k áralakulását 2005. április 22-tól vizsgáljuk. Mivel az ECX által közölt napi záróárfolyamot tekintjük egy megfigyelési egységnek, így összesen 522 mintával számolunk.

Az autokorreláció vizsgálatánál a Durbin-Watson tesztet végezzük el. A tesztstatisztika értéke $d=1,758$. A próba kritikus értékei nagy mintánál $(\mathrm{N}=522)$ 5\%os szignifikanciaszinten $d_{1}=1,52$ és $d u=1,56$. Mivel $\mathrm{d}_{\mathrm{u}}<\mathrm{d}<4-\mathrm{d}_{\mathrm{u}}$, így elfogadjuk a nullhipotézist, nevezetesen, hogy a loghozamok autokorrelálatlanok.

A következókben megvizsgáljuk, hogy a loghozamok milyen eloszlással jellemezhetók (2. ábra).

A 2. ábrán látható a hozamok hisztogramja és az eloszlás jellemzó mutatói. A minta átlaga természetszerúleg negatív, mivel a kezdeti ár lényegesen magasabb, mint a mai. A legnagyobb emelkedés $47,44 \%$-os, míg a legnagyobb csökkenés 36,3\%-os. Az elóbbi 2006 májusában következett be a nagy összeomlás után, míg a legnagyobb esés 2007. február 19-én. Az elóbbiról a későbbiekben lesz szó, míg az utóbbi elsôsorban az alacsony árfolyam következménye (1,15 €-ról 0,8 €-ra csökkent az árfolyam), illetve az ekkoriban jelentkező alacsony forgalom. Az eloszlás enyhén jobbra ferdült $(\mathrm{M} 3=-0,45)$, és a normálisnál csúcsosabb, amelyet a negyedik momentum magas értéke is jelez (M4=18,81). Ennek megfelelóen a Jarque-Bera-teszt értéke igen magas, így nincs olyan szignifikanciaszint, amely mellett azt mondhatnánk, hogy az EUA-ár loghozamai normális eloszlást követnének. Az eloszlás elsôsorban a nagy eséseknek és a kevés nagy emelkedésnek köszönhetôen vastag farkú eloszlással bír.

Összességében az EUA áralakulásának teljes idôbeni vizsgálatából kiderült, hogy a loghozamok autokorrelálatlanok, és a normálisnál csúcsosabb, vastag farkú eloszlással bírnak. Ugyanakkor a késóbbiekben rámutatunk majd arra, hogy egy-egy rövidebb idôszakot vizsgálva a hozamok normális eloszlást mutathatnak.

\section{A piaci hatékonyság három szintje}

Fama (1970) alapján a piacokat hatékonyság alapján három csoportba oszthatjuk: gyengén, közepesen és erôsen hatékonyak. A következókben definiáljuk ezeket a fogalmakat, illetve bemutatjuk mérésüket is.

\section{Gyenge hatékonyság}

Gyengén hatékonynak nevezhetünk egy piacot, ha a múltbeli információk teljesen beépültek az árakba, így azok vizsgálatából a technikai elemzók nem tudnak extra hozamra szert tenni. A hatékonyság ezen formáját sorozattesztekkel, autokorreláció-vizsgálatokkal lehet tesztelni, amelyról részletesen ír Fama (1970) és Andor et al. (2005).

\section{Közepes hatékonyság}

Ha közepesen hatékonyak a piacok, akkor nemcsak a múltbeli információk, hanem a mindenki számára elérhetô információk is beépülnek az árfolyamba. A legjobban elfogadott elemzés ennek elvégzésére az eseményelemzés (event studies), amelyet a következó fejezetben részletesen bemutatunk. Ha az új informáci- 
ók gyorsan (egy napon belül) beépülnek az árfolyamba, abban az esetben azt mondhatjuk az adott piacra, hogy legalább közepesen hatékony.

\section{Erốs hatékonyság}

Erős piaci hatékonysággal rendelkező piacon minden publikus és nem publikus információ is beépül az árfolyamba, így tartósan bennfentes kereskedelemmel sem lehet nagyobb hozamot elérni, adott kockázat mellett, mint a piac. Az erôs hatékonyság tesztelése a legnehezebb. A legelterjedtebb módszer, hogy a befektetési vállalatok hozamait elemezzük nagyon hosszú távon (5-10 év), és azt vizsgáljuk, hogy ezen időszak alatt adott kockázati szint mellett mennyivel tért el a piaci hozamtól a befektetési vállalat hozama (Komáromi, 2002).

\section{Eseményelemzés}

A következókben részletesen bemutatjuk azt a két eseményt, amely alapján keressük a választ arra a kérdésre, hogy a fenti definíció alapján közepesen hatékonynak mondhatjuk az EU-ETS piacot vagy sem.

\section{A vizsgálat alá bevont idôszakok}

A két vizsgált esemény a 2006. április végi időszak, amikor az első hivatalos adatok közzétételére került sor, míg a másik a 2006. decemberi magyar kvótaaukció.

\section{A 2006. április végi idôszak}

Minden, az ETS hatálya alá tartozó vállalatnak legkésőbb 2006. április 30-ig el kellett számolnia a 2005. naptári évre eső, független auditor által hitelesített $\mathrm{CO}_{2}$ kibocsátásával, míg az egyes országoknak május 15-ig kellett megtenni az összesített bevallást az EU Bizottság felé. Ebből kiderült, hogy az ország nettó eladó (long), vagy vevői (short) pozícióban volt. Az 1. táblázatban összefoglaljuk az EU-ETS első évének országjelentéseit, illetve feltüntetjük azon dátumokat, amelyeken egy-egy adott ország nem hivatalos kibocsátási adatait hozták nyilvánosságra. Hivatalos bejelentésnek nevezzük, ha az adott ország szervezete vagy minisztere tette a bejelentést, míg kiszivárgott információnak nevezzük a nem hivatalos kézből származó információkat.

Hollandia, Észtország és Csehország hozta először nyilvánosságra az adatokat, amelynek hatására az EUA

1. táblázat

Az EU-25 EUA sapka, a 2005. évi emisszió és a túlallokálás mértéke

\begin{tabular}{|c|c|c|c|c|c|c|}
\hline & Kvóta & Kibocsátás & Eltérés & Túlallokálás & $\begin{array}{l}\text { Kiszivárgott/ } \\
\text { elózetes } \\
\text { információ }\end{array}$ & $\begin{array}{c}\text { Hivatalos } \\
\text { nyilvánosságra } \\
\text { hozatal }\end{array}$ \\
\hline Ausztria & 32412654 & 33372841 & -960187 & $-3 \%$ & - & máj. 12. \\
\hline Belgium & 58311087 & 55314181 & 2996906 & $5 \%$ & ápr. 26. & máj. 12. \\
\hline Csehország & 96910587 & 81119194 & 15791393 & $16 \%$ & - & ápr. 25. \\
\hline Dánia & 37303720 & 26468662 & 10835058 & $29 \%$ & - & máj. 12. \\
\hline Észtország & 16742465 & 12621824 & 4120641 & $25 \%$ & - & márc. 30. \\
\hline Finnország & 44614146 & 33051851 & 11562295 & $26 \%$ & - & máj. 12. \\
\hline Franciaország & 150366284 & 131237959 & 19128325 & $13 \%$ & ápr. 26. & ápr. 28. \\
\hline Görögország & 71132212 & 71066992 & 65220 & $0 \%$ & - & máj. 12. \\
\hline Hollandia & 86452491 & 80351292 & 6101199 & $7 \%$ & ápr. 24. & ápr. 25. \\
\hline Írország & 19236747 & 22366765 & -3130018 & $-16 \%$ & - & máj. 12. \\
\hline Lengyelország & 214900000 & 184900000 & 30000000 & $14 \%$ & - & júl. 5. \\
\hline Lettország & 4070078 & 2852578 & 1217500 & $30 \%$ & - & máj. 12. \\
\hline Litvánia & 13503454 & 6603869 & 6899585 & $51 \%$ & máj. 4. & máj. 12. \\
\hline Magyarország & 30236166 & 25853325 & 4382841 & $14 \%$ & - & máj. 12. \\
\hline Nagy-Britannia & 206023033 & 237320271 & -31297238 & $-15 \%$ & márc. 30. & máj. 12. \\
\hline Németország & 494979063 & 469468333 & 25510730 & $5 \%$ & - & máj. 12. \\
\hline Olaszország & 215738709 & 221395203 & -5656494 & $-3 \%$ & - & máj. 12. \\
\hline Portugália & 36896041 & 36413004 & 483037 & $1 \%$ & - & máj. 12. \\
\hline Spanyolország & 171938192 & 181076448 & -9 118256 & $-5 \%$ & - & ápr. 26. \\
\hline Svédország & 21900000 & 19400000 & 2500000 & $11 \%$ & - & máj. 2. \\
\hline Szlovákia & 30470677 & 25231569 & 5238908 & $17 \%$ & - & máj. 12. \\
\hline Szlovénia & 9138064 & 8703921 & 434143 & $5 \%$ & - & máj. 5. \\
\hline Összes & 2063275870 & 1966170282 & 97105588 & $4,71 \%$ & & \\
\hline
\end{tabular}

Forrás: Ellerman (2006), Pointcarbon 
ára egy nap alatt 9\%-ot esett. Másnap Franciaország, Spanyolország és Belgium is nyilvánosságra hozta kibocsátási adatait, amelynek révén az árak további 30\%ot zuhantak. A korrekció egészen május 15-ig tartott, és közel a harmadára csökkent az EUA ára. Ezt követôen enyhe emelkedés következett, és az ár $15 € / t$ körül stabilizálódott. A korrekcióban nagyban közrejátszott az EU Bizottság hivatalos közleménye a kibocsátási adatokra vonatkozóan, amely a piaci szereplő́k várakozásaihoz képest 28 millió tonnával kevesebb többletról számolt be. Ezt a piac jelentôs árfolyam-növekedéssel reagálta le (8,5 €/t-ról 14,5 €/-t-ra növekedett az ár). Ebben az időszakban a kereskedési volumen is jelentôsen megnôtt, ahogyan az alábbi ábrán is látható. Az átlagos napi 1-1,5 millió tonnáról napi 3-4 millió tonnára nốtt (3. ábra).

Piaci kiigazítás a túlallokációs bejelentések hatására

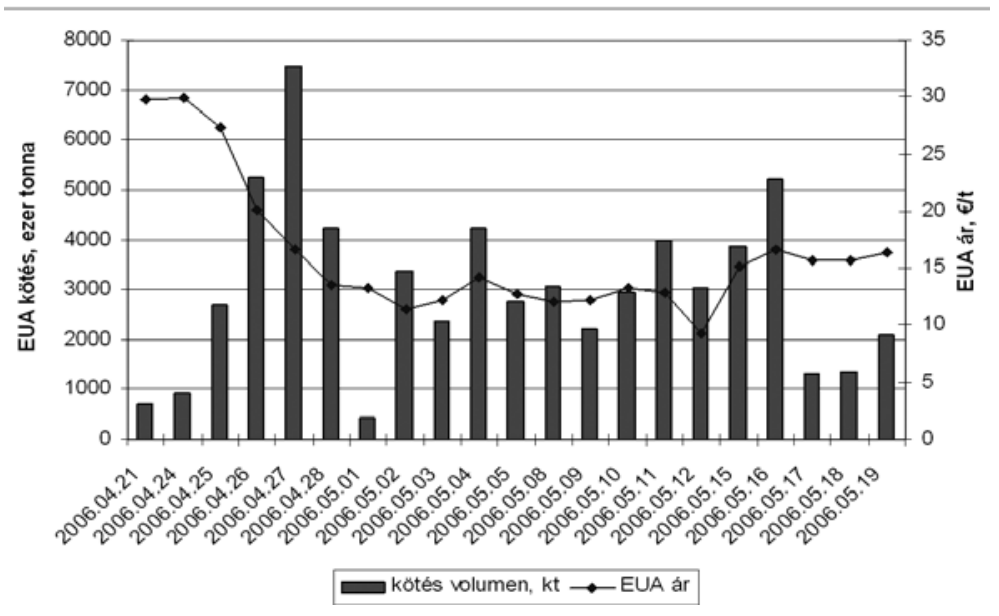

Forrás: ECX

Az elsô országjelentések megjelenése után az ár kiigazítása elkerülhetetlen volt, mivel kiderült, hogy a $\mathrm{CO}_{2}$-emissziók jóval elmaradtak a kibocsátási kvóták mennyiségétól. Ez azért történhetett meg, mert a piacok pontosan ismerték ugyan a kínálatot a nemzeti allokációs tervekből, nem ismerték viszont a kötelezett vállalatok tényleges $\mathrm{CO}_{2}$-kibocsátásait. Az erre vonatkozó információk az elsố országjelentések elôtt mindössze a vállalatok önbevallásain alapultak, amelyek rendkívül torznak bizonyultak két fó ok miatt. Az egyik, hogy a kötelezett vállalatok a nemzeti kiosztási tervek számukra kedvezó befolyásolása érdekében abban voltak érdekeltek, hogy a nemzeti hatóságaik felé a sapka megállapítása előtt a lehetô legmagasabb kibocsátásokat mutassák, és mivel ezeket a nemzeti hatóságok és az EU Bizottság is nagyrészt elfogadta, ezért a piac sem tudott mást tenni. Ezért a valós keresletet a piac 2006 áprilisáig felülbecsülte, mert korábban nem lehetett in- formációkkal alátámasztani azt a sejtést, hogy a vállalatok túl allokáltak. A torz piaci várakozások másik oka volt, hogy a vállalatok önbevallásos emisszióadatait független tanúsítók még nem vizsgálták, erre először a 2005-ös bevallások során, azaz 2006 tavaszán került sor az ETS-irányelv rendelkezései alapján.

\section{A 2006. decemberi magyar aukció}

Az EU-ETS I. időszakában (2005-2007) az EU Direktíva alapján a jelenleg müködő és az Irányelv hatálya alá eső létesítményeknek megállapított összkvóta legalább 95\%-át ingyenesen kell kiosztani az egyes vállalatok között, míg a maradék 5\%-ról az adott ország dönt, hogy ingyenesen vagy árverésen értékesíti-e. Magyarország azon kevés ország közé tartozott, amely a jogok egy részét aukción értékesítette. Az EU Bi3. ábra zottság által is jóváhagyott magyar Nemzeti Kiosztási Terv a jogok 2,5\%-ának, így összesen 2 millió 340 ezer tonna $\mathrm{CO}_{2}$-kibocsátási egység térítés ellenében történő kiosztásáról rendelkezik. A Pénzügyminisztérium 2006. november 24-én hirdetményben közzétette, hogy ezen mennyiségből 1,2 millió tonnát 2006. december 11-én elektronikus árverésen értékesít. Az árverés eredményeként kialakult „,...értékesítési ár az aukciót megelőző napon a www.pointcarbon.com internetes oldalon közzétett határidős kontraktusra vonatkozó ár mínusz 0,90 euró" (PM, 2006). A teljes éves európai kvótakínálat 2,1 milliárd jog, így az értékesített mennyiség ennek 0,057\%-a, míg a 2006. novemberi napi átlagos ECX-n történő kereskedésnek a 43\%-a. Mivel ezen a tőzsdén bonyolódik le a forgalom $75 \%$-a, így a teljes tőzsdei kereskedésnek 32\%-a.

\section{A két esemény összehasonlítása}

Kiinduló feltételezésünk, hogy az elsô vizsgált esemény teljesen új információkkal szolgált a piacnak, azaz egy ismeretlen információ vált mindenki számára ismertté. A magyar aukció ellenben egy olyan eseménynek tekinthetô, amely meglétéról a piaci szereplók a magyar Nemzeti Kiosztási Terv elfogadásával értesültek, így annak kínálatmódosító hatása beépülhetett az árba. Ha elemzésünk során azt tapasztaljuk, hogy sem az aukciót bejelentố napon, sem az aukció napján nincs abnormális hozam, akkor ezen információ beépült az árfolyamba, így legalább gyenge hatékonyságúnak mondhatjuk a piacot. Az elsố esemény elemzésével Fama értelmezése alapján a közepes hatékonyságot, míg az aukció vizsgálatával a gyenge hatékonyságot lehet tesztelni. 


\section{Az eseményelemzés módszertana}

Az eseményelemzés (event studies) azt vizsgálja, hogy egy adott eseménynek milyen hatása volt az árfolyamra. Az eseményelemzéskor létre kell hozni két, egymást nem fedő intervallumot (4. ábra).

\section{Az eseményelemzés két időszaka}

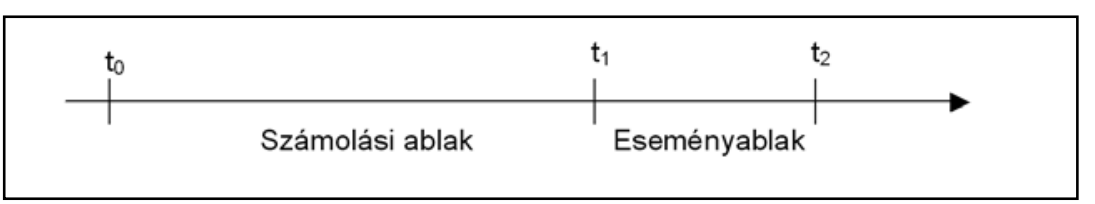

Forrás: MacKinley (1997), p.: 20

Az elsố intervallum a számolási ablak, ahol a normál hozamokat mérjük, míg a második az eseményablak, amelyben található egy olyan esemény, amelynek a hatását vizsgálni szeretnénk. Megmérjük, hogy a számolási ablakban mekkora az átlagos hozam és szórás, és azt vizsgáljuk, hogy az eseményablakban lévô hozamok lényegesen eltérnek-e a számolási ablakban lévóktől. Ha szignifikáns különbséget tapasztalunk, akkor azt mondhatjuk, hogy olyan új információ épült be ezzel az árfolyamba, amely még nem tükröződött az árakban. Ellenben, ha nem találunk statisztikailag kimutatható különbséget, akkor azt mondhatjuk, az esemény nem tartalmazott új információt (Brown et al., 1985:7. o.).

Az eseményelemzésnél három lényeges kulcskérdés van. Az alkalmazott modell, az ablakok hossza, illetve a hozamok megválasztása (órás, napi, havi).

\section{Alkalmazott modell}

Az irodalom megkülönböztet statisztikai és közgazdasági modelleket. Az elóbbi az értékpapírok hozamainak vizsgálatából indul ki, míg az utóbbiak alapja valamilyen közgazdasági feltételezés. Az elóbbibe tartozik többek között az átlagos hozam modell és a piaci modell, míg az utóbbiba, többek között, a CAPM modell (Dyckman et al., 1984).

\section{Átlagos hozam modell}

Legyen R a normális hozam, amely a számítási ablakban lévő hozamok átlaga, míg $R_{t}$ egy adott napon megfigyelt hozam. A kettő különbsége adja az abnormális hozamot: $\mathrm{AR}_{\mathrm{t}}=\mathrm{R}_{\mathrm{t}}-\check{\mathrm{R}}$

A kumulált abnormális hozam az eseményablakban lévő hozamok átlaga.

$$
C A R=\frac{\sum_{t_{1}}^{t_{2}} A R_{t}}{N}, \begin{gathered}
\text { ahol } \mathrm{N} \text { az eseményablak hossza } \\
\left(\mathrm{N}=\mathrm{t}_{2}-\mathrm{t}_{1}\right)
\end{gathered}
$$

A vizsgált nullhipotézis, hogy a CAR-k 0 várható értékkel bírnak, aminek vizsgálata t-próbával történik. A t statisztika értéke:

$$
\text { 4. ábra } \theta=\frac{C A R}{s} \text {, ahol }
$$


értékek határozhatják meg a becsült paramétereket, amelyek már idejétmúltak. MacKinlay (1997) alapján a számolási ablak hossza ötven vagy száz tagból kell, hogy álljon, így számolásaink során mi is az eseményt közvetlenül megelőzô ötven-, illetve százelemú mintát használtuk. Az eseményablak hosszával kapcsolatban Dyckman et al. (1984) hangsúlyozza, hogy minél rövidebb az eseményablak, annál könnyebb kimutatni az abnormális hozamot. Ellenben ha az eseményablakot túl hosszúnak választjuk, akkor több új információ is belekerülhet az elemzésbe, így az eredmény torzított lesz. A szerzók kiindulásként háromnapos, illetve ennél rövidebb eseményablak meghatározását látják célszerünek. Dolgozatunkban mi egy-, kettó-, illetve háromnapos hosszal számolunk. Az egynapos eseményablak azért indokolt, mivel a 2006. április végi időszakban igen gyakran látott napvilágot olyan hír, amely jelentôs hatást gyakorolt az EUA árfolyamára, ezért egy-egy hír hatásának vizsgálata csak rövid eseményablak mellett lehetséges. A háromnapos eseményablak megválasztása pedig kvázi kontrollként múködik.

\section{Hozamok}

Elemzésünk során mindenképpen a napi hozamok mellett döntünk, mivel az EU-ETS piac egy viszonylag új, és ezáltal rövid kereskedési időszakkal bír, így napi hozamoknál ritkább adatok esetén nem állna rendelkezésre elegendő adat. Ugyanakkor célszerú lenne órás hozamokkal számolni, amely különösen hasznos lenne a 2006. április végi idôszaki elemzéshez, amikor egy nap több jelentős hatású információ épülhetett be az árakba. Ez azonban az órás adatok hiánya miatt nem lehetséges.

\section{Az eseményelemzés a két vizsgált eseményre}

A következókben megvizsgáljuk az eseményelemzés eszközével, hogy a szén-dioxid-kvótapiacon mi minősül új információnak, mi tudja megváltoztatni az árfolyamot. Ezt két példán keresztül ismertetjük, amelyet fent részletesen tárgyaltunk: a 2006. április végi időszakot, illetve a 2006-os magyar kvótaaukciót. Elemezzük, hogy ezen események elôtt száz, illetve ötvennapos intervallumban normálisnak tekinthető-e a loghozamok eloszlása, ezt követóen pedig az esemény utáni abnormális hozam meglétét vizsgáljuk. Célunk annak a kérdésnek az eldöntése, hogy legalább közepesen hatékonynak tekinthetô-e ez a piac.

\section{A normalitás tesztelése a számolási ablakokban}

Az előző fejezetben elvégeztük a loghozamok normalitástesztjét, és megállapítottuk, hogy az egész idôszakot vizsgálva a loghozamok vastag farkú elosz- lással bírnak. Ha azonban rövidebb időszakot vizsgálunk, akkor a hozamok normális eloszlással jellemezhetóek, mivel a nagy árfolyammozgásokkal bíró napok kikerülnek a vizsgálatból.

2. táblázat

50, illetve 100 napos számolási ablak esetén a Jarque-Bera-teszt alapján elvégzett normalitástesztelés p értékei

\begin{tabular}{|c|c|c|}
\hline \multirow{2}{*}{} & \multicolumn{2}{|c|}{ Számolási ablak (t $\left.\mathbf{t}_{\mathbf{1}}-\mathbf{t}_{\mathbf{0}}\right)$} \\
\cline { 2 - 3 } & 100 nap & 50 nap \\
\hline 2006. 04. 21. & $12,89 \%$ & $\mathbf{3 , 4 0 \%}$ \\
\hline 2006. 04. 24. & $9,45 \%$ & $\mathbf{1 , 3 0 \%}$ \\
\hline 2006. 04. 25. & $5,54 \%$ & $\mathbf{0 , 0 0 \%}$ \\
\hline 2006. 04. 26. & $\mathbf{0 , 0 0 \%}$ & $\mathbf{0 , 0 0 \%}$ \\
\hline 2006. 04. 27. & $\mathbf{0 , 0 0 \%}$ & $\mathbf{0 , 0 0 \%}$ \\
\hline 2006. 04. 28. & $\mathbf{0 , 0 0 \%}$ & $\mathbf{0 , 0 0 \%}$ \\
\hline 2006. 05. 01. & $\mathbf{0 , 0 0 \%}$ & $\mathbf{0 , 0 0 \%}$ \\
\hline 2006. 05. 02. & $\mathbf{0 , 0 0 \%}$ & $\mathbf{0 , 0 0 \%}$ \\
\hline 2006. 11.23. & $\mathbf{0 , 0 0 \%}$ & $7,30 \%$ \\
\hline 2006. 11.24. & $\mathbf{0 , 0 0 \%}$ & $7,60 \%$ \\
\hline 2006. 12. 08. & $\mathbf{0 , 0 7 \%}$ & $55,10 \%$ \\
\hline 2006. 12. 11. & $\mathbf{0 , 1 3 \%}$ & $59,50 \%$ \\
\hline
\end{tabular}

Forrás: saját számítás

2. táblázatban ötven-, illetve száznapos idôsoron vizsgáljuk, hogy az eseményt megelőző napokon normális eloszlással jellemezhető-e a minta. Szignifikáns eredménynek fogadjuk el, ha a p értéke 5\% felett van, ebben az esetben azt mondhatjuk, hogy közel normális eloszlással közelíthetố a minta. A száznapos hozamok vizsgálatánál mindössze három olyan napot találunk, amelyet megelőzően normális volt a minta eloszlása. Ez a vizsgált időszak elsố három napja (április 21., április 24. és április 25.). Ha ötvenelemú mintával vizsgáljuk a táblázatban feltüntetett napokat megelôző nap hozamait, akkor az eloszlásuk már nem tekinthetố normálisnak. Ennek a magyarázata, hogy a mintának jelentôsen csökkent a szórása, így növekedett a csúcsossági és a ferdeségi mutató értéke is. Az ötvennapos adatsorokat vizsgálva normális eloszlással jellemezhetố azonban a november 23., november 24., illetve a december 8. és december 11-e elôtti idôszak, ami azzal magyarázható, hogy kikerült egy olyan idôszak, amely nem normális eloszlással bír.

A fentiekból nem egyértelmúen eldönthetô, hogy az ötven-, vagy a száznapos idősor alkalmasabb-e az eseményelemzés elvégzésére, így dolgozatunkban mindkettôt bemutatjuk. 


\section{Az abnormális hozam vizsgálata}

A fent bemutatott módszertannal megvizsgáljuk az április 21. - május 2. közti időszakot, a magyar aukciót kihirdetố és az azt megelőzố napot (november 23., november 24.), illetve az aukciót megelôzô és az aukció napját is. A 3. táblázatban a p-értékeket tüntettük fel. Szignifikáns eredménynek vesszük azt, ha a p értéke nem volt jelentôs áresés, így az abnormális hozamok átlaga nem tér el szignifikánsan 0-tól.

Az ötven-, illetve száznapos számolási ablak összesen egyetlen helyen ad különbözó eredményt. Május 1-jén kétnapos eseményablakkal számolva, száznapos számolási ablak esetén azt mondhatjuk, hogy kimutatható 0-tól eltérố szignifikáns hozam, míg ötvennapos

Különböző hosszúságú eseményablak és számolási ablak melletti p-értékek

\begin{tabular}{|c|c|c|c|c|c|c|}
\hline \multirow{4}{*}{$\begin{array}{c}\text { A vizsgált } \\
\text { esemény napja } \\
\left(t_{1}\right)\end{array}$} & \multicolumn{6}{|c|}{ Számolási ablak hossza $\left(t_{1}-t_{0}\right)$} \\
\hline & & 100 & & & 50 & \\
\hline & \multicolumn{3}{|c|}{ Eseményablak hossza $\left(t_{-}-t_{1}\right)$} & \multicolumn{3}{|c|}{ Eseményablak hossza $\left(t_{2}-t_{1}\right)$} \\
\hline & 1 & 2 & 3 & 1 & 2 & 3 \\
\hline 2006. 04. 21. & $27,78 \%$ & $40,71 \%$ & $28,22 \%$ & $24,57 \%$ & $42,94 \%$ & $28,48 \%$ \\
\hline 2006. 04. 24. & $44,71 \%$ & $0,70 \%$ & $3,20 \%$ & $37,37 \%$ & $\mathbf{0 , 0 3 \%}$ & $0,64 \%$ \\
\hline 2006. 04. 25 . & $0,00 \%$ & $0,00 \%$ & $0,00 \%$ & $0,00 \%$ & $0,00 \%$ & $0,00 \%$ \\
\hline 2006. 04. 26. & $0,00 \%$ & $0,00 \%$ & $0,00 \%$ & $0,00 \%$ & $0,00 \%$ & $0,00 \%$ \\
\hline 2006. 04. 27. & $0,00 \%$ & $0,00 \%$ & $\mathbf{0 , 0 0 \%}$ & $0,02 \%$ & $0,01 \%$ & $0,00 \%$ \\
\hline 2006. 04. 28. & $0,00 \%$ & $0,59 \%$ & $\mathbf{0 , 0 3 \%}$ & $0,04 \%$ & $3,46 \%$ & $0,44 \%$ \\
\hline 2006. 05. 01. & $35,64 \%$ & $3,36 \%$ & $0,20 \%$ & $44,63 \%$ & $10,61 \%$ & $1,78 \%$ \\
\hline 2006. 05. 02. & $0,06 \%$ & $21,31 \%$ & $24,47 \%$ & $0,99 \%$ & $32,43 \%$ & $36,10 \%$ \\
\hline 2006. 11. 23. & $26,68 \%$ & $20,77 \%$ & $36,30 \%$ & $24,39 \%$ & $19,76 \%$ & $32,06 \%$ \\
\hline 2006. 11. 24. & $15,52 \%$ & $26,68 \%$ & $26,84 \%$ & $15,95 \%$ & $24,84 \%$ & $24,50 \%$ \\
\hline 2006. 12. 08. & $20,45 \%$ & $23,28 \%$ & $38,34 \%$ & $25,64 \%$ & $28,41 \%$ & $37,10 \%$ \\
\hline 2006. 12. 11. & $26,66 \%$ & $22,53 \%$ & $21,61 \%$ & $32,46 \%$ & $28,40 \%$ & $26,79 \%$ \\
\hline
\end{tabular}

Forrás: saját számítás

kisebb mint 5\%, ebben az esetben azt mondhatjuk, hogy olyan hír épült be az árfolyamba, amely jelentős hatással bírt annak árfolyamára.

Láthatjuk a 3. táblázatból, hogy április 21., 24., május 1., november 23., november 24., december 8. és 11én minden vizsgált hosszúságú számolási ablak mellett elfogadjuk a nullhipotézist, azaz nem következett be olyan esemény, amely jelentôs hatást gyakorolt volna a piacokra. Április 25., április 26., április 27., április 28. és május 2-án nagyon nagy valószínúséggel kijelenthetjük, hogy történt olyan esemény, amely jelentősen befolyásolta az árfolyamot.

Az egy-, két-, illetve háromnapos eseményablakból azonos következtetéseket vonhatunk el. Összesen három napon tér el a kapott eredmény az eseményablak hosszúságától függő́en. Április 24-én két-, illetve háromnapos eseményablak esetén azért mutatható ki abnormális hozam, mivel mindkét esetben belekerül az elemzésbe a következő nap, amikor jelentős mértékú esés következett be. Hasonló okok miatt tér el a kapott eredmény május 1-jét vizsgálva is. Május 2-án kettő, illetve háromnapos eseményablakkal vizsgálva azt mondhatjuk, hogy a következő és a megelőző napon számolási ablak esetén nem. Ennek az oka, hogy az ötven naposban nagyobb súllyal szerepelnek a nagy esések, így növelve a szórást, ezáltal csökken a t értéke és növekszik az elfogadási tartomány.

\section{A hírek összevetése az eseményelemzéssel}

Ahhoz, hogy mondhassunk valamit arról, hogy mi gyakorol jelentős hatást a piacokra, szükséges elemezni, hogy a vizsgált napokon milyen hírek láttak napvilágot, amelyek jelentősen befolyásolhatták az áralakulást. Ennek érdekében a Pointcarbon portálon feltüntetett híreket elemezzük, mivel ez a legnagyobb olyan oldal, amelyet naponta többször frissítenek, és itt megjelenik minden olyan hír, amely hatással lehet a szén-dioxid-kvótaárakra.

A mellékletben olvasható a vizsgált napokon érkezet összes hír, míg a 4. táblázatban azokat tüntettük fel, amelyek áralakító hatással bírhatnak.

A hírek egy része a második időszakra vonatkozott, azonban ezeknek is jelentős hatásuk lehet az első időszaki árakra. Ha például egy olyan információ kerül napvilágra, amely egyértelmúen drágítja a 2008-12-es EUA-árakat (pl. sapka csökkentése), abban az esetben 
A vizsgált idôszakokban azon hírek, amelyek jelentôs hatással bírhattak a kvótaárfolyamokra

\begin{tabular}{|c|c|c|}
\hline Dátum & Hír rövid tartalma & $\begin{array}{l}\text { A hír hatása } \\
\text { az árfolyamra }\end{array}$ \\
\hline 2006. 04. 24. & $\begin{array}{l}\text { A holland emisszió kisebb mint a várt, nyilatkozta egy névtelenségét kérố } \\
\text { holland hivatalnok. }\end{array}$ & - \\
\hline 2006. 04. 25. & $\begin{array}{l}\text { A cseh környezetvédelmi miniszter szerint a csehországi vállalatok 15\%-kal } \\
\text { kevesebbet bocsátottak ki, mint a részükre kiosztott kvóta mennyisége. }\end{array}$ & - \\
\hline 2006. 04. 25. & $\begin{array}{l}\text { A Dutch Emissions Trading Authority megerôsítette, hogy a kibocsátás } \\
6,1 \text { millióval meghaladta a kiosztott mennyiséget. }\end{array}$ & - \\
\hline 2006. 04. 26. & $\begin{array}{l}\text { A vallon régió kibocsátása 15\%-kal kisebb, mint az allokált mennyiség, } \\
\text { nyilatkozta egy névtelenségét kérố belga hivatalnok. }\end{array}$ & - \\
\hline 2006. 04. 26. & $\begin{array}{l}\text { A francia kibocsátás } 11,6 \% \text {-kal kisebb, mint a kiosztott mennyiség, nyilatkozta } \\
\text { a környezetvédelmi miniszter. }\end{array}$ & - \\
\hline 2006. 04. 26. & $\begin{array}{l}\text { A spanyol kibocsátás } 10,9 \mathrm{M} \mathrm{t} \text {-val meghaladja a kiosztott mennyiséget, } \\
\text { mondta a spanyol környezetvédelmi miniszter. Az árfolyam ennek ellenére esett, } \\
\text { mivel nagyobb hiányt vártak a piacok. }\end{array}$ & - \\
\hline 2006. 04. 28. & $\begin{array}{l}\text { A hivatalos francia kibocsátási adatok alapján Franciaország } 19 \text { M t long } \\
\text { pozícióban van. }\end{array}$ & - \\
\hline 2006. 04. 28. & $\begin{array}{l}\text { Bulgáriában a kormány elutasította a környezetvédelmi miniszter által beadott } \\
\text { NAP-ot, több kvótát követelve a villamosenergia-termelő vállalatoknak. }\end{array}$ & - \\
\hline 2006. 05. 02. & $\begin{array}{l}\text { Svédország 2,5 M t-val longvan van, nyilatkozta a fenntartható minisztérium } \\
\text { munkatársa. }\end{array}$ & - \\
\hline 2006. 05. 02. & $\begin{array}{l}\text { Az EC megkérte a tagállamokat, hogy ne hozzák nyilvánosságra a kibocsátási } \\
\text { adatokat május 15-ig. }\end{array}$ & + \\
\hline 2006. 05.02. & A svéd kibocsátási adatok miatt ismét esett az árfolyam. & - \\
\hline 2006. 12.08. & $\begin{array}{l}96300 \text { t-t értékesített hét különböző vevőnek 6,87 €/t-s egységes árfolyamon } \\
\text { az ír kormány. }\end{array}$ & $0 /-$ \\
\hline 2006. 12.11. & Magyarország 1,197 M t-t értékesített aukción 7,42 €/t-s árfolyamon. & $0 /-$ \\
\hline
\end{tabular}

Forrás: Pointcarbon

egyes vállalatoknak érdemes lehet már most csökkenti a kibocsátásukat és határidôre eladni a még ki nem osztott kvótákat is. Ez azonban csak akkor lehet hatékony stratégia, ha a második kiosztási lista módszertana eldöntött, vagyis az esetleges jelen időszaki döntés nincs hatással a kapott kvóta mennyiségére, például ha a kapott kvótát a 2005-ös év vagy valamilyen benchmark alapján kapják meg a vállalatok. Mivel a vizsgált két időszakban viszonylag kevés ország bírt az Európai Bíróság által jóváhagyott második nemzeti kiosztási tervvel, így minden egyes információt, amely a második időszakra vonatkozott, semleges információnak vettük (EC, 2007).

Egyes esetekben nem egyértelmúen eldönthetô, hogy az adott hír árcsökkentố vagy árnövelő hatású. Ezek közé tartozik például az országok éves kibocsátási adatainak bevallása. Ebben az esetben ugyanis nem a hiányt vagy a többletet kell nézni, hanem a várakozá- sokhoz képesti többletet vagy hiányt. Erre nyilvánvalóan nincsen mód, így az árak alakulásából következtethetünk arra, hogy az milyen hatással bírt a kvóta árára.

\section{Az áprilisi áresés}

$\mathrm{Az}$ április áreséskor összesen nyolc napot vizsgálunk meg, amelyból a következóket állapíthatjuk meg az abnormális hozamok és a hírek elemzése alapján:

- Április 21-én nem érkezett semmilyen olyan információ, amely jelentős hatást gyakorolhatott volna az árfolyamra. Az abnormális hozamokat vizsgálva is ezt az eredményt kapjuk.

- Április 24-én az árak emelkedtek, annak ellenére, hogy a holland longpozíció nagyobb, mint a várt. Ennek egyértelmú negatív hatása kellene, hogy legyen az árakra, ugyanakkor ezen információ nem 
hivatalos forrásból származott, így nem biztos, hogy jelentôs hatással lehetett az árakra. Abnormális hozam nem mutatható ki.

- Április 25-én mind a hírek, mind az eseményelemzés azt mutatja, hogy jelentős csökkenés következett be. Ez két ok miatt lehetséges. Egyrészt a csehek 15\%kal kevesebbet bocsátottak ki, másrészt a hollandok hivatalosan is nyilvánosságra hozták az adatokat. Ez azt erősíti meg, hogy a kiszivárgott információknak nincsen piacmozdító hatásuk, mivel a hivatalos közlés után esett az árfolyam, nem pedig a kiszivárgott információ hatására. A napközbeni árfolyammozgások arra utalnak, hogy elsősorban a holland közlés hatására csökkent az ár, kisebb mértékben a cseh adatok miatt.

- Április 26-28. között több ország hivatalosan is nyilvánosságra hozta az adatait. Ezek közé tartozott a Vallon régió, Franciaország és Spanyolország. Mindhárom ország a várthoz képest kisebb kibocsátási adatot jelentett be, amely erôsen éreztette a hatását is. Mindegyik napon igen meredek áreséssel szembesülünk, amelyet a hozamok vizsgálata is kimutatott.

- Május 1-jén a piacok zárva voltak, ennek ellenére kismértékú kereskedés folyt, és az árak csak igen kis mértékben estek. A módszertan alapján azonban nem beszélhetünk jelentős mértékú esésről, mivel az árfolyamcsökkenés megfelelt a számolási ablakban lévő árfolyam-ingadozáséval, azaz az abnormális hozam nem tér el szignifikánsan 0-tól.

- Május 2-án ismét jelentős esés következett be, amely elsôsorban a svéd kibocsátási adatoknak volt köszönhető, amit alátámaszt az eseményelemzés is.

Összességében az áprilisi adatok elemzéséból azt állapíthatjuk meg, hogy a kiszivárgott információknak nincsen jelentôs szerepük, illetve az információk gyorsan beépülnek az árakba. Ezt támasztja alá, hogy május 3-án emelkedtek az árak, tehát a megelőző napokban érkezett hírek nagyon gyorsan beépültek az árfolyamba. Ennek alapján azt mondhatjuk, hogy megállja a helyét azon állítás, hogy az EU-ETS közepesen hatékony piacnak tekinthetô.

\section{A magyar aukció}

A magyar aukciót vizsgálva az a kiinduló feltevésünk, hogy nem tapasztalunk abnormális hozamot sem az aukció napján, sem a bejelentés napján, és ez alapján a piacot legalább gyenge hatékonyságúnak nevezhetjük. A másik magyarázat szerint azért lehetséges, hogy nem tapasztalunk abnormális hozamot, mivel az aukcionált mennyiség viszonylag kicsi, így nem bír jelentôs kínálatmódosító hatással.
November 21-én, a kihirdetést megelőzó napon, illetve november 24-én is emelkedtek az árak, így a kihirdetésnek nem volt árcsökkentő hatása. December 8-án, az aukciót megelőzố napon, kis csökkenéssel találkozhatunk, ugyanakkor 0-tól eltérô szignifikáns abnormális hozamról nem beszélhetünk, annak ellenére, hogy ezen a napon volt az ír aukció, amely során 960 ezer tonnát árvereztek el. December 11-én nem történt különösebb változás, bár a hírek szerint a magyar aukció után csökkent valamelyest az ár, ám ez gyorsan korrigálódott, így nem volt jelentôs abnormális hozam. Ezek alapján a magyar árverezett mennyiséget a piaci szereplók már korábban a kínálat részének tekintették.

\section{A két eseményelemzés eredményei}

Az előzőekben elemeztük, hogy a vizsgált két időszak alatt milyen olyan hírek láttak napvilágot, amelyek jelentősen befolyásoltak az EUA árát. A példák kapcsán rámutattunk arra, hogy a kiszivárgott híreknek nincsen hatásuk az árakra, csak a hivatalos bejelentés bír olyan erővel, amely képes jelentős hatást gyakorolni az árakra. A másik megállapításunk, hogy a magyar aukciónak nem volt egyáltalán statisztikailag kimutatható hatása az árakra, így legalább gyengén hatékonynak nevezhetjük ezen piacot, mivel a múltbeli információ már korábban beépült az árakba.

Mivel május 1-jén és május 4-én nem látott napvilágot olyan hír, ami jelentôsen befolyásolta volna az árakat, így ezeken a napokon nem esett (jelentôsen) az árfolyam, amiból arra következtethetünk, hogy a viszonylagos új, még jelentôsen alakulóban lévô piac ellenére az árak az összes múltbeli és jelenbeli információt tartalmazzák, ezért Fama (1970) csoportosítása alapján a piacot közepes hatékonyságúnak mondhatjuk. Az erôs piaci kritérium, amely szerint minden bennfentes információ is beépül az árba, nem volt célunk vizsgálni, így sem elvetni, sem cáfolni nem tudjuk az erôs piaci hatékonyságot.

\section{Összefoglalás}

Dolgozatunkban vizsgáltuk az EUA árfolyamának alakulását, illetve az EUA loghozamainak eloszlását. Megállapítottuk, hogy hosszú idôsort vizsgálva a hozamok autokorrelálatlanok, ugyanakkor a normálisnál jelentôsen csúcsosabb eloszlással jellemezhető. Azonban rövidebb intervallumok elemzésénél (50 vagy 100 nap) lehetséges egyes esetekben azt mondani, hogy normális eloszlással jellemezhetô az EUA-hozamok eloszlása.

Az eseményelemzés eszközével két eseményt vizsgáltunk meg részletesen. A 2006. április végi-május eleji idôszakot, amikor a 2005. évi bevallások hatására az ár 
néhány nap alatt a harmadára esett vissza, illetve a 2006. évi magyar árverést. Ezen két esetból megállapíthatjuk, hogy hasonló eredményt kapunk, ha ötven-, illetve száznapos eseményablakkal számolunk. A piac csak a hivatalos országbevallásokat fogadja el, a kiszivárgott információknak nincsen jelentős hatása az árakra.

A két példa alapján megállapítottuk, hogy a szenynyezési jogok piaca Fama (1970) csoportosítása alapján legalább közepes hatékonyságúnak mondható, mivel minden múltbeli és jelenlegi, publikus információ beépül az árfolyamba.

\section{Felhasznált irodalom}

2003/87/EC Irányelv az Európai Kibocsátás Kereskedelmi Rendszerről, http://www.kvvm.hu/klima/dokumentum/ pdf/ETS\%20direktiva\%20vegleges.pdf, 2007.05.10.

Andor Gy. - Bicskei B. - Ormos M. - Hernádi P. - Szabó G. (2005): Befektetés és finanszírozás I. kötet - Tókepiaci árazódás és a racionális vállalati gazdasági elemzés; http://www.mvt.bme.hu/imvttest/segedanyag/25/Befekt etesUesUfinanszirozas.pdf; 2007. 05. 15.

Bedó T. (2006): A választások hatása a Budapesti Értéktőzsdére, kézirat, Budapest

Brealey, R.A. - Myers, S.C (1998): Modern vállalati pénzügyek, Panem Könyvkiadó, Budapest

Brown, S.J. - Warner, J.B. (1980): Measuring Security Price Performance; Journal of Financial Economics 8, 205258. o.

Brown, SJ. - Warner, J.B. (1985): Using Daily Stock Returns: The Case of Event Studies; Journal of Financial Economics 14., 14-31. o.

Dyckman, T. - Philbrick, D. - Stephan, J. (1984): A Comparison of Event Study Methodologies Using Daily Stock Returns: A Simulation Approach; Journal of Accounting Research, Vol. 22, Studies on Current Econometric Issues in Accounting Research, 1-30. o.

EC (2005): EU action against climate change;

http://ec.europa.eu/environment/climat/pdf/emission trading3_en.pdf, 2007.08.08.

EC (2007): National Allocation Plans: Second Phase (20082012); http://ec.europa.eu/environment/climat/ 2nd phase_ep.htm, 2007.05. 15.

Ellermann, D. - Buchner, B. (2006): Over-allocation or abatement? A preliminary analyses of the EU ETS Based on the 2005 emission data; http://www.feem. it/Feem/Pub/Publications/WPapers/WP2006-139.htm, 2007. 04. 10.

Fama, E.F. - Fisher L. - Jensen, M.C. - Roll, R (1969): The Adjustment of Stock Prices to New Information; International Economic Review, Vol. 10, No. 1., 1-21. o.

Fama, E.F. (1970): Efficient Capital Markets: A Review of Theory and Empirical Work; The Journal of Finance, Vol. 25, No. 2, 383-417. o.
Fama, E.F. (1991): Efficient capital markets: II; The Journal of Finance; Vol. 46., No. 5, 1575-1645. o.

GKM (2003): Tájékoztató az EU kibocsátáskereskedelmi rendszeréról és annak magyarországi bevezetéséról

IEA (2007): CO2 Allowance And Electricity Price Interaction Impact on Industry's Electricity Purchasing Strategies in Europe; IEA information Paper; http://www.iea.org/ textbase/papers/2007/jr_price_interaction.pdf, 2007. 04. 12.

Kerekes S. (1998): A környezetgazdaságtan alapjai, Budapest, Aula, 1998

Komáromi Gy. (2002): A hatékony piacok elméletének elméleti és gyakorlati relevanciája, Közgazdasági Szemle, Vol. 49, 377-395. o.

Lesi M. - Pál G. (2005): A szén-dioxid emisszió kereskedelem elméleti alapjai és európai uniós szabályozása, Pénzügyminisztérium Kutatási Füzetek 11.

Mackinley, A.C. (1997): Event Studies in Economics and Finance, Journal of Economic Literature. Vol. 35, No. 1, 13-39. o.

Molnár M. A. (2006): A Budapesti Értéktőzsde hatékonysága, Hitelintézeti Szemle, Vol. 5, No. 5-6, 28-35. o.

Paolella, M.S. - Taschini, L. (2006): An Econometric Analysis of Emission Trading Allowances; http:// papers.ssrn.com/sol3/papers.cfm?abstract_id $=947055$, 2007. 04. 11.

$P M$ (2006): Szén-dioxid-kvótát értékesít a magyar állam; http://www2.pm.gov.hu/web/home.nsf/(PortalArticles)/16E33E2BD62E2D0EC125723000652CB6, 2006. 12. 05 .

Pointcarbon (2004): What Determines the prices of Carbon?; http://www.pointcarbon.com/wimages/Carbon_Market_ Analyst_special_oct_823767.pdf, 2006. 10. 10.

Pointcarbon (2007): Carbon 2007 - A new climate for carbon market, http://www.pointcarbon.com/getfile. php/fileelement_105366/Carbon_2007_final.pdf, 2007. 05. 10.

Saens, R. - Sandoval, E. (2005): Measuring Security Price Performance Using Chilean Daily Stock Returns: The Event Study Method, Cuadernos de Economia, Vol. 42, 307-328. o.

Sijm, J.P.M. - Bakker, S.J.A. - Chen, Y. - Harmsen, H.W. - Lise, $W$ (2006): CO2 price dynamics, the implications of EU emissions trading for the price of electricity, http://www.ecn.nl/docs/library/report/2005/c05081.pdf, 2007. 04. 12.

\section{Internetes oldalak}

www.pointcarbon.com www.vertisfinance.com http://www.ecxeurope.com http://www.nordpool.n

Cikk beérkezett: 2007. 9. hó Lektori vélemény alapján átdolgozva: 2008. 2. hó 
A vizsgált idôszakokban érkezố hírek és azok áralakító hatásai

\begin{tabular}{|c|c|c|}
\hline Dátum & Hír rövid tartalma & $\begin{array}{l}\text { A hír hatása } \\
\text { az árfolyamra }\end{array}$ \\
\hline 2006. 04. 21. & Semmi hír nem érkezett, enyhe mozgás a piacon. & 0 \\
\hline 2006. 04. 24. & Délután egy órakor az EUA árfolyama átlépte a 30 €/t-s árat. & 0 \\
\hline 2006. 04. 24. & $\begin{array}{l}\text { A holland emisszió kisebb, mint a várt, nyilatkozta egy névtelenségét kérô } \\
\text { holland hivatalnok. }\end{array}$ & - \\
\hline 2006. 04. 24. & A nap elején gyors emelkedés, majd csökkenés, végül 30 €/t alatt zárt az árfolyam. & 0 \\
\hline 2006. 04. 25. & $\begin{array}{l}\text { A cseh környezetvédelmi miniszter szerint a csehországi vállalatok 15\%-kal } \\
\text { kevesebbet bocsátottak ki, mint a részükre kiosztott kvóta mennyisége. }\end{array}$ & - \\
\hline 2006. 04. 25. & $\begin{array}{l}\text { A holland környezetvédelmi miniszter szerint a második idôszakban ugyanennyi } \\
\text { kvótát terveznek kiosztani, csak több lesz a szabályozás alá bevont létesítmények } \\
\text { száma. }\end{array}$ & 0 \\
\hline 2006. 04. 25. & $\begin{array}{l}\text { A Dutch Emissions Trading Authority megerósítette, hogy a kibocsátás } \\
6,1 \text { millióval meghaladta a kiosztott mennyiséget. }\end{array}$ & - \\
\hline 2006. 04. 25. & $\begin{array}{l}\text { Az ár egy óra alatt a holland vártnál kisebb kibocsátási adatok hatására 3,5\%-ot } \\
\text { esett. }\end{array}$ & 0 \\
\hline 2006. 04. 25. & $\begin{array}{l}\text { Összesen } 10 \% \text {-ot esett az ár egy nap alatt a verfikált adatok nyilvánosságra } \\
\text { kerülése miatt. }\end{array}$ & 0 \\
\hline 2006. 04. 26. & $\begin{array}{l}\text { A vallon régió kibocsátása } 15 \% \text {-kal kisebb, mint az allokált mennyiség, } \\
\text { nyilatkozta egy névtelenségét kérő belga hivatalnok. }\end{array}$ & - \\
\hline 2006. 04. 26. & Az árfolyam továbbra is csökken, elsôsorban a Vallon kibocsátási adatok hatására. & 0 \\
\hline 2006. 04. 26. & $\begin{array}{l}\text { A francia kibocsátás } 11,6 \% \text {-kal kisebb, mint a kiosztott mennyiség, } \\
\text { nyilatkozta a környezetvédelmi miniszter. }\end{array}$ & - \\
\hline 2006. 04. 26. & $\begin{array}{l}\text { A spanyol kibocsátás } 10,9 \mathrm{M} \text { t-val meghaladja a kiosztott mennyiséget, mondta a } \\
\text { spanyol környezetvédelmi miniszter. }\end{array}$ & - \\
\hline 2006. 04. 27. & 13,5 és 20 €/t között mozgott az árfolyam. & 0 \\
\hline 2006. 04. 28. & $\begin{array}{l}\text { A hivatalos francia kibocsátási adatok alapján Franciaország } 19 \text { M t long } \\
\text { pozícióban van. }\end{array}$ & - \\
\hline 2006. 04. 28. & A francia kibocsátási adatok hatására az ár 13,5 €/t-ra esett le. & 0 \\
\hline 2006. 04. 28. & $\begin{array}{l}\text { Bulgáriában a kormány elutasította a környezetvédelmi miniszter által beadott } \\
\text { NAP-ot, több kvótát követelve a villamosenergia-termelő vállalatoknak. }\end{array}$ & - \\
\hline 2006. 04. 28. & $\begin{array}{l}\text { Olaszország egy hónappal kitolja a vállalatok kibocsátásbejelentési } \\
\text { kötelezettségének végső határidejét. }\end{array}$ & 0 \\
\hline 2006. 05. 02. & $\begin{array}{l}\text { Svédország 2,5 M t-val longvan van, nyilatkozta a fenntartható minisztérium } \\
\text { munkatársa. }\end{array}$ & - \\
\hline 2006. 05. 02. & $\begin{array}{l}\text { Az EC megkérte a tagállamokat, hogy ne hozzák nyilvánosságra a kibocsátási } \\
\text { adatokat május 15-ig. }\end{array}$ & + \\
\hline 2006. 05. 02. & A svéd kibocsátási adatok miatt ismét esett az árfolyam. & - \\
\hline 2006. 11. 23 . & $\begin{array}{l}\text { Csökkent a kereskedési mennyiség, mivel a kereskedók zárták a pozíciókat a } \\
\text { 2006-os évre vonatkozóan. }\end{array}$ & 0 \\
\hline 2006. 11. 24. & $\begin{array}{l}\text { A német környezetvédelmi miniszter állítása szerint a második időszakban } 17 \\
\text { millió tonnával kevesebb jogot osztana ki Németország. }\end{array}$ & 0 \\
\hline 2006. 11. 24. & Hatnapos rekordot döntött az ár délben, amikor 9,15 €/t-n kereskedtek vele. & 0 \\
\hline 2006. 11. 24. & A spanyolok a második időszakban 16\%-kal akarnak kevesebbet kiosztani. & 0 \\
\hline
\end{tabular}




\begin{tabular}{|c|c|c|}
\hline Dátum & Hír rövid tartalma & $\begin{array}{l}\text { A hír hatása } \\
\text { az árfolyamra }\end{array}$ \\
\hline 2006. 12. 08. & A jelentős eladások miatt csökkent az ár. & 0 \\
\hline 2006. 12.08. & $\begin{array}{l}\text { Magyarország 2007. januárig nem készíti el a második NKT-t, de előrehaladás } \\
\text { van az AAU szabályozásában. }\end{array}$ & 0 \\
\hline 2006. 12. 08. & $\begin{array}{l}963000 \text { t-t értékesített hét különbözó vevônek 6,8 €/t-s egységes árfolyamon az ír } \\
\text { kormány. }\end{array}$ & $0 /-$ \\
\hline 2006. 12.08. & Írország a második NKT-ben, 1,15 M t-ra növelné az aukción értékesíthető mennyiséget. & 0 \\
\hline 2006. 12.11. & Magyarország 1,197 M t-át értékesített aukción 7,42 €/t-s árfolyamon. & $0 /-$ \\
\hline 2006. 12. 11. & $\begin{array}{l}\text { 0,25 €-t esett az árfolyam, mivel a kereskedônek nem értik, hogyan lehetett magasabb } \\
0,62 \text { €-val a magyar aukción értékesített kvóta ára, mint a tőzsdei kereskedési ár. }\end{array}$ & 0 \\
\hline 2006. 12.11. & $\begin{array}{l}\text { 5\%-ot esett a CER-ek ára az elmúlt két hétben, mivel az EC kiadott egy szigorú } \\
\text { szabályozást ezek felhasználásáról. }\end{array}$ & 0 \\
\hline
\end{tabular}

Forrás: Pointcarbon

A vizsgált napokon az árfolyam és az elôzô naphoz képesti változás

\begin{tabular}{|c|c|c|}
\hline & $\begin{array}{l}\text { Adott napi záróárfolyam } \\
\qquad(€ / t)\end{array}$ & $\begin{array}{c}\text { Az elózó napihoz képesti loghozam } \\
(\%)\end{array}$ \\
\hline 2006. 04. 21. & 30,75 & $-0,6 \%$ \\
\hline 2006. 04. 24. & 30,95 & $0,6 \%$ \\
\hline 2006. 04. 25. & 28,30 & $-9,0 \%$ \\
\hline 2006. 04. 26. & 20,75 & $-31,0 \%$ \\
\hline 2006. 04. 27. & 17,30 & $-18,2 \%$ \\
\hline 2006. 04. 28. & 14,25 & $-19,4 \%$ \\
\hline 2006. 05. 01. & 13,95 & $-2,1 \%$ \\
\hline 2006. 05. 02. & 11,95 & $-15,5 \%$ \\
\hline 2006. 05.03. & 12,85 & $7,3 \%$ \\
\hline 2006.11 .23$. & 9,00 & $1,1 \%$ \\
\hline 2006. 11. 24. & 9,20 & $2,2 \%$ \\
\hline 2006. 12. 08. & 7,30 & $-3,4 \%$ \\
\hline 2006. 12. 11. & 7,10 & $-2,8 \%$ \\
\hline
\end{tabular}

Forrás: Pointcarbon, ECX

\section{O N T E N T S}

\section{HETESI, Erzsébet - KÜRTÖSI, Zsófia}

Who values the quality of higher education services and how? - The student satisfaction measuring models, empirical research results in the active students and alumni groups

\section{HOVÁNYI, Gábor}

Compatible management of corporate networks A guide to developing the contemporary management of a network

\section{STUdies AND ARTICLES}

\section{KISS, János}

Product development and business performance

\section{FUTÓ, Péter}

Impact assessment of enterprise regulatory II. part ....... 32

\section{NÉMETHNÉ PÁL, Katalin - PETZ, Raymund}

Enterprise opinions about the competition

MEZÖSI, András

18 Analysis of efficience of the EU-ETS market 51 